\title{
Opportunities and Challenges of College Tourism Undergraduate Students Employment in Tourism Industry
}

\author{
Xiaoyang Li \\ School of Tourism and Cuisine, Harbin University of Commerce, Harbin, P.R.China, 150076 \\ Email:tanxiao9@126.com
}

\begin{abstract}
China's tourism has entered the country's strategic system, facing the unprecedented development climax. To make tourism industry become strategic pillar industry of national economy and modem service industry of the people better satisfaction, we must have a high quality professional talent team. Tourism colleges undertake task of training high-quality professionals, college tourism undergraduates must become mainly strength that tourism development depends on. University tourism graduates are facing new opportunities and challenges; they must seize the opportunities and meet challenges, and provide wit support for China to build the world tourism power country.
\end{abstract}

Keywords-undergraduates of college tourism major; employment; opportunities; challenges

\section{INTRODUCTION}

On December, 1st, 2009, the 41st file announced by the government "Opinion on the state council about speeding up the development of tourism " pointed out: To make tourism industry become strategic pillar industry of national economy and modem service industry of the people better satisfaction. Opinion identified our country tourism developmental goal: By 2015, tourism market scale will further expand, domestic tourists will be 33 billion person-times, entry overnight tourists will be 9000 million person-times, and outbound tourists will be 8300 million person-times. Tourism consumption will grow steadily, urban and rural residents annual take part in tourism will be over 2 times, tourism consumption will be equivalent to $10 \%$ of the total residents' consumption. Economic and social benefit will be more evident, annual tourism revenues grow above $12 \%$, tourism added value account for national GDP proportion will increase to 4.5 , and account for service industry proportion will increase to $12 \%$. Annual new increase tourism employment will be 50 million. Tourism service quality will improve obviously, market order will be better obviously, sustainable development ability enhance obviously, by 2020, China tourism industry's scale, quality and deficiency will basically reach the world tourism power country's level. The promulgation of the opinion marked tourism industry into the national strategic system and indicated China tourism industry will usher in a new round developmental climax.

If industry wants to develop, talents are the key. To build a tourism power country, priority is accelerate to implement strategy of science and education revitalizing tourism and talents strong tourism, cultivate and build a high-quality travel talent team who adapt to the developmental requirement of modern service industry. It has significant meaning to analyze opportunities and challenges that the university tourism major undergraduates are facing.

With the development of tourism discipline, foreign tourism education research is more, and the tourism education and tourism undergraduate's employment relationship is less. Such as: John Lennon from the tourism education purpose put forward the tourism education occupation relevance and practical applicability. Goodenough and Page put forward a viewpoint that should pay attention to the close relationship between the tourism education and industry. For the domestic on tourism students employment problem research mainly concentrated in the employment " mismatches" and the difficult employment in tourism industry, mainly related to tourism personnel training mode, supply and demand situation, higher tourism education situation and reform, tourism management specialty students' employment tendency, employment competitiveness. Such as "Investigation and Study of TalentCultivation Mode in Tourism Institutions" (Li et al., 2009), "Satisfaction Degree on Geography Major and Employment Expectation for the Students Majoring in Tourism Management" (zhu, 2008), etc.

This paper uses literature research method, according to the national related policy, the statistics data of National Tourism Bureau, etc, researches opportunities and challenges of college tourism undergraduate students employment in tourism industry.

\section{OPPORTUNITY}

\section{A. Tourism Booming Development Causes the Huge Demand to Professionals}

According to the World Tourism Organization's up-to-date forecast, China will be the world's top international tourist destination country in 2005 and the world's fourth-largest international tourist source areas. At that time, China tourism industry's scale will be six times than the one right now. The vigorous development of tourism industry will trigger a great demand of tourism talents. The World Tourism Organization 
predicted, by 2015 , direct national tourism employment will reach 1700 million, and indirect employment will reach 8300 million. According to the preliminary estimates, at present, the national tourism practitioners are 600 million. With the development of tourism, the actual need professionals are up to 800 million. The lack of tourism talents is at least 300 million. In the future, this gap will also increase with 200,000 each year. Among them, the senior manager's demands will reach about 7 million by 2010 , and at present only 3 million; tourism guide's demands is 30 million, but at present the number is around 20 million, the gap is 10 million. Tourism industry has broad employing space [1].

\section{B. Tables Tourism Development of Internationalization Causes the Huge Demand to High Quality Professionals}

According to the World Tourism Organization's recently 3 years report of The Tourism Competitiveness, China's tourism competitiveness is rising continuously, already from 71 in 2007 (within 124 countries and area), rising to 47 in 2009 (within 133 countries) and is one of the fastest rising country in worldwide[2].

The World Tourism Organization predicted, by 2020, China could exceed France which currently ranked first as the most popular tourist destination country in the world. China successfully held 2008 Beijing Olympic Games and 2010 Shanghai World Expo, demonstrates that China has formed the internationalization open tourism concept. China's international tourism development is toward the world advanced level and the demand to talented people is to an unprecedented high.

\section{Solving the Employment Problem Causes the Huge Demand to Professionals}

China's tourism industry associates national economy 109 industries and 39 departments. The development of relevant industry has varying degree promoting effect to the development of tourism industry. According to the material published by the World Tourism Organization, when tourism industry increases a direct employment opportunity, social can add 5-7 indirect job opportunities. Visibly, as a modern service industry's head and pillar, tourism industry has become China's an important channel to increase employment opportunities, alleviate employment pressure. Employment is vital to people's livelihood. During the "12.5" period, China's tourism will enter the best development period and a rapid growth stage. Tourism industry scale will continue expand, the industrial structure will be gradually optimized, industry quality will be obviously increased, industrial function will effectively release. Tourism will become important strength to expand domestic demand, adjust structure, promote the growth and benefit the people's livelihood.

\section{Government' Great Importance Causes the Huge Demand to Professionals}

Including "the State Council about speeding up the development tourism opinion ", Hainan International Tourism Island, the West Coast Economic Zone, Guangxi North Bay, Shandong Yellow River Delta, Jiangsu Coastal Areas, Liaoning Coastal Economic Belt, Poyang Lake related regional eco- tourism policy, and the regional policy of supporting national regions such as Xinjiang, Xizang's development, successively have 25 items national strategy or regional planning to make tourism as one of important development contents. Many cities attach great importance to tourism, from Hainan constructing international tourism island to Yunnan implementing tourism second pioneer, from Guangdong launching national leisure plans to Henan province established "Tourism support province" strategic, and Jiangsu, Zhejiang, Beijing, Tianjin and other cities extend the tourism consume coupons, etc. Tourism dominated by the government has been further strengthened. It is reported that at present 27 provinces have established tourism as the pillar industry or the third industry bibcock. The Chinese government correct and forceful policy guaranteed the stable and rapid development of Chinese tourism industry." the World Tourism Organization secretary-general Rifai said [3].

\section{CHALLENGES}

\section{A. Conflict between Tourism Market Needs and High- Quality Talents Shortage}

At present, our country tourism relatively short talents have three categories. The first is the tourism enterprise high-end management talents, including top managers in the human resources development and management, marketing, tourism entertainment management, tourism planning, tourism scenic spots management and tourism property management, etc. The second are some new professional talents with tourism development, such as electronic business affairs, timeshare vacation travel, convention-exhibition tourism, tourist capital operation talents. The last is the international tourism talent. Hot outbound tourism business makes tourism talents who mastering outbound business managers, plan scheduling, advertising planning and ticket reservation, visa, first-line group with overseas travel link, become hot person every travel agencies want to scramble.

\section{B. Conflict between Tourism Market Needs and Serious Talents Loss}

Tourism enterprises as services, which talents turnover is far above other industries. General industry normal personnel loss is at $5 \%-10 \%$, however, tourism enterprises staff loss rate is unexpectedly above $20 \%$. The data from the universities employment instruction centre showed that many tourism graduates have changed to do other industries because of prejudice to service industry. Among people who holding tourism guide qualification certificate, 65471 guides have no longer engaged in this field, account for $33.2 \%$. Among them, holding qualification certificate loss rate is $45.3 \%$, holding primary certificate loss rate is $6.4 \%$, holding intermediate certificate loss rate is $14.6 \%$, holding high certificate losing is for $10.1 \%$, holding super certificate losing is for $37 \%$ [4].

\section{Conflict between Tourism Market Needs and Industry Practitioners' Average Quality and Degree Lower}

Tourism personnel average quality and degree lower is also one cause of making the current talents crisis. Take tourism guide for example, high school (technical secondary school) 
diploma accounts for $41.7 \%$, and college diploma accounts for only $39.4 \%$. Foreign language tourism guide degree is higher than Chinese classes, but college and below is still 52\%, especially a few languages tourism guide is very scarce ${ }^{[5]}$.From the perspective of tourism guide configuration, tourism guide team by certificate and primary card are majority, achieves $96.3 \%$, medium, senior and super guide are only accounted for $3.7 \%$, only 27 super guides in China ${ }^{[6]}$.

\section{Conflict between Tourism Market Needs and College Tourism Education Obviously Lag}

The rapid development of tourism has great demand to all levels talents. But from the current industry needs and talent cultivation status, college tourism education is slower than industrial development. In 1998,common colleges undergraduate course professional directory promulgated, "Cultivate senior specialized talents and talents with management, economics, laws, folk culture and tourism professional knowledge who can work at all levels from the tourism administration department to enterprises engaged in tourism management. Cultivate research potential who can work and investigative tourism teaching, scientific. "s result, the students have learned everything, but they didn't master it. Excessive high training target makes the talents' cultivation cannot be implemented.

\section{E. Conflict between Tourism Market Needs and College Graduates Overall Employment Situation Severe}

According to "the China Statistical Yearbook", Ministry of Education, "China education career development status statistics bulletin", from 1999 to 2011, the number of college graduates rapidly rose: 85 million, 107 million, 115 million, 145 million, 212 million, 280 million, 338 million, 413 million, 495 million, 559 million, 611 million, 630 million, 680 million. China's higher education came into "pop" era at the beginning of the $21 \mathrm{st}$. From the perspective of the labour supply and demand, new labour force in human resource market will reach 15 million, among of them, college graduates will more than 63 million, but year-round can provide jobs more than 12 million, supply greater than demand contradiction is very sharp. In current and several future years, China's total employment situation will be quite severe, university graduate employment overall difficulty will further increase. It also means that more not travel major graduates will enter tourism industry and participate in employment competition.

\section{F. Conflict between Tourism Market Needs and Employment Field in the Industry is Too Centralized}

Tourist hotels, travel agencies and scenic area are regarded as the three pillars of tourism. According to "the 2009 China tourism statistics yearbook" statistics, by the late 2008, the national tourism enterprises and institutions employees include travel agencies, star-rated hotels, tourism scenic spots will be
272.13 million, Star-rated hotel employees were about $61 \%$, other units' personnel include travel agencies, spots and tourist transport companies only $12 \%$ and $27 \%{ }^{[7]}$. Tourism employment mainly concentrated in the hotel, tourism scenic spots, travel agencies which absorbing employment potential was not fully released.

\section{G. Conflict between Tourism Market Needs and Industry Recognition Degree Low}

Industry approval refers the consistency degree that between graduates have learned major and the job that who later will pursue, it reflects the industry to student's appeal and in the marketplace competition. We can reflect the approval of the tourism industry by tourism graduates on tourism industry department's employment. Prejudice from working intensity, income level, and public opinion cause attractive of tourism as labor-intensive service industry to talents is less. Recent years, tourism major undergraduate employment works in tourism industry are commonly $10 \%-20 \%$. It is worth to see that college tourism major graduates select tourist hotels, travel agencies to employ are less and less. More students application and have learned are not consistent.

\section{CONCLUSION}

In short, strong development momentum and the remarkable economic achievements presented by modern tourism not only greatly expand the tourism specialized talented demand space, but also put forward higher request and goals to tourism professional talents, especially senior tourism specialized talents. College tourist major undergraduates should more base on the tourism industry employment, give full play to its own professional advantage, service in tourism development needs, to realize higher tourism education value maximized.

\section{REFERENCES}

[1] Cao, Y., Wu, Y., FEI, L. (2010). Tourism Development in China and Countermeasures. Hunan Agricultural Machinery, 7,126-128

[2] Zhang, G. (2010). China is Not Referred to as a "World Tourism power country. China Social Science News, 6,4 .

[3] Li, X. (2010). United Nations official: the Global Tourism Income Concentrated in Asia, Especially in China. Huxi City news.

[4] Wu, D., Wang,L., Wang, S., Zhu, T., Wang, Y. (2010). Necessity, Possibility and Strategic Measures for Building Tourism into a Strategic Pillar Industry. China Soft Science, 11,1-5.

[5] National Tourism Administration: 2010 National Tourism Education and Training Statistics

[6] Liu, X., Zhang, P. (2007). Studies of Occupational Expectation of Graduates in Tourism Colleges. Journal of Chengdu University (Natural Science Edition, 2,79-86

[7] National Tourism Administration: 2010 China Star Hotels Statistical Bulletin 